and perfectly smooth; the leaflets from 2 to 3 inches long, and an inch or more in breadth, rounded or slightly cordate at the base, the lower ones in pairs supported on petiolules of 2 to 3 lines long, while the terminal one has a petiolule of an inch in length; and the terminal corymb expands almost into a panicle. The combined fruit, after dehiscence, measures fully half an inch across. In some respects the plant appears to approach Euodia melicefolia, Benth.= Megabotrya meliafolia, Hance=Boymia gla-

brifolia, Champ., but differs widely in the character of the fruit, in the crenulate margin of the leaflets, and in the pubescence of their nerves, none of which characters are indicated in the several descriptions of the plant of Southern China. A northern plant, Phellodendron Amurense, Rupr. in 'Bull. Acad. St. Petersb.' and in 'Maxim. Prim. Flor. Amur.' p. 73, t. 4, also bears considerable resemblance in its habit, in the size and composition of the leaves, and in the form of the leaflets, but, if the fruit be correctly figured, is very different indeed."

\title{
EXPLANATION OF PLATE V.
}

Fig. 1. Xanthoxylum (Oxyactis) Danielli; leaf and inflorescence, twothirds of the natural size.

Fig. 2. Separate carpella, of the natural size.

Fig. 3. Seeds, of the natural size.

XXI.-On some additional Species that are common to Carboniferous and Permian Strata; with Remarks on the Recurrency of Carboniferous Species. By James W. Kirkвy.

[Plate IV.]

IN a former paper, where I noticed the occurrence of a Permian Lingula in the Durham Coal-measures, a list was given of such species as were then known to be common to the Carboniferous and Permian life-groups*. Since the publication of that paper, Mr. Davidson has shown that some additional Brachiopods may be placed on the list of Carboniferous recurrents $\dagger$; and the present communication is chiefly made for the sake of identifying three forms of Entomostraca and Polyzoa belonging to the Carboniferous series with species that have hitherto been considered exclusively Permian, and thus to still further increase the list of these recurrent forms.

The Carboniferous fossils were sent to me, along with others, by Messrs. H. W. Crosskey and J. Young, of Glasgow, from the

* Quart. Journ. Geol. Soc. vol. xvi. p. 415.

$\dagger$ Mon. Brit. Carbon. Brach. (Palæont. Soc.), pp. 265-268, pl. 54. 
marine shales and limestones of that district. The Permian fossils with which they have been compared are from the Magnesian Limestone of Durham. Two of the species are Entomostraca of the subgenus Bairdia; the other is a Polyzoan of the genus Fenestella.

\section{Cythere (Bairdia) plebeia, Reuss, 1854.}

Permian specimens, Pl. IV. figs. 7, 8, 10; Carboniferous specimens, Pl. IV. figs. 5, 6, 9.

Type-specimens of B. plebeia are moderately inflated, have a subdeltoid carapace, a leuticular lateral contour, and smooth surface. The posterior extremity is more or less acute and rostrated; the anterior extremity is much deeper and rounded. It is a species, however, that possesses considerable latitude of form, nine varieties having already been described by Mr. T. R. Jones and myself $*$.

The Carboniferous Entomostraca which are identified with this species agree in all the above characters, as well as in others of minor importance. This, I think, will be evident from the figures given of specimens from both formations.

The Carboniferous specimens, which do not seem to have been hitherto noticed, occur in dark-grey shale at Craigenglen, Campsie.

\section{Cythere (Bairdia) Schaurothiana, Kirkby, 1858.}

Permian specimens, Pl. IV. figs. 3, 4, 12 ; Carboniferous specimens, Pl. IV. figs. 1, 2, 11 .

B. Schaurothiana is a larger Entomostracan than the preceding species. It is somewhat elongate and almost subhexagonal in outline; the posterior extremity is angulate, and not much produced, its upper half being formed by an abrupt descent of the dorsal margin; the anterior extremity is broad, rounded, and at times subangulate above; the lateral contour is more or less lenticular, and the surface is smooth.

The Carboniferous specimens which I place with this species are generally of larger size and more robust than Permian examples; and in some specimens the ventral margin anteriorly becomes more prominent than I have ever seen it in Schaurothiana, but this is probably concomitant with an increase of development. In all essential particulars they agree with the characters of the species to which they are referred, there being, so far as I can observe, no point of specific difference between

* Trans. Tynes. Nat. Field Club. vol. iv. pp. 141-146 and 161, 162. 
them. And it should be mentioned that this is not my opinion only, but that of Mr. T. Rupert Jones, to whom I submitted for examination specimens of both the present species and the preceding, each of which he referred to the Permian species named.

\section{Fenestella retiformis, Schlotheim, 1816-17.}

Syn. Fenestella plebeia, M`Coy, 1844.

Permian specimens, Pl. IV. figs. 13, 16, 17; Carboniferous specimens, Pl. IV. figs. 14, 15, 18.

Among other Polyzoa that I have received from my Glasgow friends are numerous specimens of a Fenestella, labelled $F$. plebeia, which so closely resembles $\boldsymbol{F}$. retiformis of the Permian rocks that $I$ have no doubt as to both being the same species. The specimens are from Beith, and occur, in a more or less fragmentary state, on the weathered surfaces of a hard dark-grey limestone. Generally speaking, they are less robust than welldeveloped Permian examples; and many of them have scarcely so many cells to the fenestrule as have normal specimens of the latter. But some specimens have precisely the same number of cells, which is about three to the fenestrule, or, rather, eleven to the four fenestrules. Prof. M'Coy having described the species from specimens possessing "four or five cells to the fenestrule," this would seem to be a variable character, and one that cannot be subjected to very exact comparison. In both Permian and Carboniferous specimens the ribs or interstices have the same relative strength compared with the dissepiments, and they branch in the same way, and are connected by similar dissepiments, which thus give to the fenestrules identity of form. Both have the reverse or uncelluliferous face covered with moderately coarse longitudinal striæ; and the cellule-apertures are more or less circular in each. All the Carboniferous specimens I have seen are somewhat worn, and do not show the raised margins of the cellule-apertures, which well-preserved Permian examples often retain, as represented in fig. 17: when worn specimens of both are compared, no difference is to be observed in this feature.

It is just possible that the Beith specimens may be erroneously identified with Fenestella plebeia of $\mathrm{M}^{\prime} \mathrm{Coy}$; for the figures of that species in his 'Syn. Char. Carboniferous Fossils of Ireland' certainly do not agree so closely with specimens of $\boldsymbol{F}$. retiformis as they. But, however this may be, there would scarcely seem any doubt of $\boldsymbol{F}$. retiformis being specifically undistinguishable from the Beith specimens. 


\section{List of Species occurring in Carboniferous and Permian Strata in Britain.}

\section{Carboniferous Name.}

1. Gyracanthus formosus, Agassiz.

2. Terebratula sacculus, Martin, 1809. Figured in Davidson's Monograph of Carboniferous Brachiopoda, pl. 54 .

3. Spirifera Urii, Fleming, 1828. Figured in Dav. Mon. Carb. Brach. pl. 54 .

4. Spiriferina octiplicata, J. de C. Sow. 1827. Figured in Mon. Carb. Brach. pl. 54 .

5. Camarophoria crumena, Martin, 1809. Figured in Mon. Carb. Brach. pl. 54 .

6. Camarophoria rhomboidea, Phillips, 1836. Figured in Mon. Carb. Brach. pl. 54 .

7. Athyris Royssii, L'Eveillé, 1835. Figured in Mon. Carb. Brach. pl. 54 .

8. Discina nitida, Phillips, 1836. Figured in Mon. Carb. Brach. pl.54. 9. Lingula mytiloides, Sow. 1812. Figured in Mon. Carb. Brach. pl. 54.

10. Fenestella plebeia, M`Coy, 1844. Figured in plate accompanying present paper.

11. Cythere elongata, Münster, 1830. Jahrbuch f. Min. p. 65.

12. Cythere inornata, M`Coy, 1844. Figured in Syn. Char. Carb. Foss. pl. 23.

13. Cythere (Bairdia) gracilis, M'Coy, 1844. Figured in Syn. Char. Carb. Foss. pl. 23.

14. Cythere (Bairdia) plebeia, Reuss (Kirkby). Figured in the plate accompanying present paper.

15. Cythere (Bairdia) Schaurothiana, Kirkby. Figured in the plate accompanying present paper.

16. Pinites Brandlingi, Lindley.

17. Trigonocarpum Næggerathi, Brong.

18. Sigillaria reniformis, Brong.

19. Calamites incqualis(?), Lindl.

20. approximatus, Brong.

\section{Permian Name.}

G. formosus, Ag., King, in Mon. Perm. Foss. England, p. 221; Howse, Ann. Nat. Hist. ser. 2. vol. xix. p. 33 .

T. elongata, var. sufflata, Schloth. 1816. Figured in Davidson's Monograph of Carboniferous Brachiopoda, pl. 54 .

S. Clannyana, King, 1848 . Figured in Mon. Carb. Brach. pl. 54.

S. cristata, Schloth. 1816. Figured in Mon. Carb. Brach. pl. 54.

C. Schlotheimi, Von Buch, 1834. Figured in Mon. Carb. Brach. pl. 54.

C. globulina, Phillips, 1834 . Figured in Mon. Carb. Brach. pl. 54.

A. pectinifera, J. de C. Sowerby, 1840. Figured in Mon. Carb. Brach. pl. 54 .

D. Konincki, Geinitz, 1848. Figured in Mon. Carb. Brach. pl. 54.

L. Credneri, Geinitz, 1848. Figured in Mon. Carb. Brach. pl. 54.

L. retiformis, Schloth. 1816-17. Figured in the plate accompanying present paper.

C. elongata, Münster (Jones). Figured in Mon. Perm. Foss. pl. 18; and Trans. Tyne. Field Club, vol. iv. pl. 11.

C. inornata, M'Coy (Jones). Figured in Mon. Perm. Foss. pl. 18; Trans. Tyne. Field Club, vol.iv.pl. 11.

C. (Bairdia) gracilis, $\mathbf{M}^{`} \mathrm{Coy}$ (Jones). Figured in Mon. Perm. Foss. pl. 18; and Trans. Tyne. Field Club, vol. iv. pl. 11.

C. (Bairdia) plebeia, Reuss. Figured in the plate accompanying present paper.

C. (Bairdia) Schaurothiana, Kirkby. Figured in the plate accompanying present paper.

For the occurrence of these species in the Rothliegende, see Howse on the Permian Fossils of Northumberland and Durham, in Annals Nat. Hist. ser. 2. vol. xix. p. 38. 
Though palæontologists have long been aware of strong resemblances existing between Carboniferous and Permian fossils, it is only of late years that the extent and value of such resemblances have been made the subject of careful inquiry. Among those who have wrought at this subject, there is perhaps no one who has produced greater results than Mr. Thomas Davidson. Most of the Brachiopods of the preceding list have been shown to be both Carboniferous and Permian by his investigation. And this authority is of the greatest value on the subject, and will be held conclusive by most palæontologists. I have, however, been able to examine and compare specimens of most of the species myself, and thus in some degree to corroborate the conclusions of this distinguished investigator. For an account of Mr. Davidson's researches, I must refer the reader to his valuable 'Monograph of Carboniferous Brachiopoda,' and to a paper on "Scottish Carboniferous Brachiopoda" in the "Geologist.' But I would more particularly direct attention to plate 54 of the Monograph, in which Carboniferous and Permian individuals of each of the Brachiopods identified are figured side by side, for the sake of comparison. The other species of the list have been determined by Mr. T. Rupert Jones, Mr. R. Howse, Prof. King, and myself. And it should not be forgotten that this list is the result of a very partial investigation of Permian and Carboniferous species. The Brachiopoda have certainly been pretty well examined, but this is the only class that has. In other classes much remains to be done; so it is possible that future research may still further increase the number of Carboniferous recurrent species, even in Britain. Had those species which foreign authors consider to be common to Carboniferous and Permian strata been included, the list would have received important additions. Dr. Geinitz, for example, states that some of the plants of the Saxon Rothliegende are identical with Coal-measure species*, as might, indeed, have been suspected from the intimate relation that exists between the flora of these rocks in Britain. M. Gœppert even asserts that there are fourteen Permian plants referable to Carboniferous speciest. The interblending of Carboniferous and Permian forms in North America would also seem to be considerable; and American palæontologists have already pointed out cases of recurrency among the species of these formations. According to Dr. F. B. Shumard, Producta semireticulata, Martin, and Spirifera camerata, Morton, so well known as Carboniferous fossils, occur in the Permian rocks of the Gaudalupe Mountains

* See Dr. Geinitz on the Coal Formation of Saxony, as noticed in Jour. Geol. Soc. vol. xiii. p. exxviii.

† Schlesische Gesellsch., Naturwiss. Sektion, 1858. 
of Texas and New Mexico*. And it has lately been shown by Dr. Prout that the Permian Polyzoan, Polypora biarmica, Keyserling, is a Carboniferous species in the western states of the same continent + . And there is little doubt, when the Permian and Carboniferous species of this region become better known, that other examples of recurrency will come to light. The generic relations of these life-groups are certainly more intimate in America than in Europe, as is evident from the occurrence there of Orthocerus, Bellerophon, and Phillipsia $\ddagger$ as Permian types; and it will be somewhat remarkable if their specific relations are not found to be as close.

It is by such inquiries as the present that palæontologists will ultimately be able to speak with more precision than they can now on the amount of relationship that exists between the lifegroups of formations, and to arrive at juster estimates of the relative value they possess as expressions of periods of geological time. And though there is no reason to assume that we are in a position to speak precisely in the present instance, it must yet be evident that the relations that exist between the Carboniferous and Permian fossils are most intimate-more so, apparently, than usually obtain in the fossils of distinct systems of strata; for this intercommunity of species is accompanied, as palæontologists are well aware, by a more than usual intercommunity of genera, most of the common types of Permian strata being Carboniferous genera as well as Permian. This close alliance of life-groups, viewed in conjunction with other evidence, caused me, in a former paper, to question the propriety of our considering the Permian series of rocks a distinct system. It was there pointed out that its importance as a stratigraphical group is much less than that of other palæozoic systems of strata; and that its life-phenomena, viewed either numerically in respect to species, or generically in regard to the introduction of new types, were of less consequence than those of systems, whether palæozoic or of later age $\S$. Recent investigations have strengthened this opinion. To use the term "system" in speaking of the Permian group of rocks would seem to imply similarity of value with other groups, such as the Silurian and Carboniferous, to which the term more appropriately applies. It would apparently indicate that it was of about equal importance in geological classification, in the history of past life, and as the expression of an interval of time, as either of the later groups, which I think few geologists will be inclined to grant. It therefore seems

* Trans. Acad. Science of St. Louis, vol. i. pp. 389, 391.

† Ibid. p. 440.

¥ Ibid. pp. 388, 399, 400.

$\ddagger$ Quart. Journ. Geol. Soc. vol. xvi. pp. 417, 419 . 
more in harmony with sound classification to employ a term indicative of less magnitude than "system" in speaking of the Permian strata. This some geologists already do, and, among others, Sir Roderick Murchison, who, in his later contributions to science, refers to the Permian strata as a group rather than a system*. But I would further observe that, in adopting a divisional term less likely to lead to wrong impressions in respect to the importance of the Permian group of rocks, it does not follow that the group should lose its distinctive appellation by being considered but a formation or subformation of the Carboniferous system. I do not advocate this in the least, being satisfied that it would tend to confuse rather than improve geological classification ; for, notwithstanding its close palæontological relations with the last-named system, it would be useless denying that its fossils are sufficiently peculiar to warrant the employment of the special designation of Permian.

In a paper on Carboniferous recurrent species lately published in the 'Edinburgh New Philosophical Journal' (vol. xiv. pp. 3745, \& vol. xv. pp. 251-253), Professor William King objects to some of the identifications of the Brachiopods of the preceding list. His objections are chiefly confined to the identification of Spirifera Urii with Sp. Clannyana, King, though other species are made the subject of remarks. Considering the position that Prof. King holds as an authority on species, it will perhaps be well to notice the grounds of his objections, though I shall do so somewhat briefly.

Spirifera Urii and Sp. Clannyana.-In respect to these shells, Prof. King maintains that they are distinct species, and that neither the one nor the other was common to Carboniferous and Permian faunæ. In support of these opinions, he says that "Urii differs from Clannyana in being a wider shell; it has an umbone more incurved; the area of the small valve not so deep; the small valve flatter, and more excavated, as it were, towards the posterio-lateral angles ; the spines decidedly less numerous, and the median sulcus more pronounced in both valves." Without disputing the existence of these peculiarities in some examples of Sp. Urii, I must still remark that in others, which I have examined myself, there are no such differences to be observed. In these specimens there exist an agreement of general form, relative length and width, convexity and sulcation of valves, size and shape of area, incurvation of umbone, and spinosity of surface, with well-preserved individuals of Sp. Clannyana, that could scarcely have occurred had they been distinct species. In fact, there is no character, that I can see, on which to separate

* Siluria, 3rd ed., and "On the Inapplicability of the Term Dyas," \&c. Philosophical Magazine, S. 4. vol. xxiii. p. 65. 
them; and if they are to be kept apart, it will certainly be upon other than palæontological grounds. But figures form better evidence than assertions either way; and I would refer to $\mathrm{Mr}$. Davidson's representations of both Carboniferous and Permian specimens, given in his Monograph of Carboniferous Brachiopoda, pl. 54, and ask if it is possible to do otherwise than agree with that gentleman in identifying these two forms as one species.

It must be acknowledged that it is not difficult to procure specimens of $S p$. Urii that show considerable differences when compared with others of Clannyana; for this species is no exception to others in possessing considerable individual differentiation. And it would seem to be with some of the most aberrant of these that Prof. King has instituted his comparison. The existence of such differences, however, can scarcely be of much value, when they are wanting in other individuals allowed to belong to the same species. At least, if the contrary is held, in the face of a knowledge of their exceptional character, it would certainly be more in harmony with the evidence to divide the Carboniferous specimens into two species than to separate them from those occurring in the Permian rocks.

One difficulty which, until a recent period, had to be contended with in comparing Carboniferous with Permian examples of this shell was the imperfect condition in which most of the latter occurred, nearly all being in the state of casts. Under such circumstances it was not, perhaps, surprising that some doubt should exist among palæontologists on the propriety of identifying the two forms; but this difficulty is now removed by the acquisition of testiferous Permian examples, one of which Mr. Davidson has figured in the plate previously mentioned.

It may also be observed that there is generally a difference in the size of the Permian and Carboniferous examples-those of Clannyana being almost invariably smaller than specimens of Urii. And though few palæontologists will be inclined to attach much value to this as a specific character, it should yet be pointed out that it is a peculiarity shared by many other Permian shells when they are compared with those of Carboniferous rocks. Permian Mollusca, as a rule, never attain the proportions of Carboniferous, so far, at least, as those of British strata are concerned.

Camarophoria crumena and C. Schlotheimi.-Though Prof. King disputes the identity of these shells, he admits the Permian species to be recurrent from the Carboniferous Limestone. The point of difference, therefore, between him and Mr. Davidson is merely whether the Carboniferous shell, which the latter has compared with $C$. Schlotheimi, is correctly identified with Ann. \& Mag. N. Hist. Ser. 3. Vol. x. 
Martin's figures of his Anomites crumena in 'Petrif. Derbiensia.' $\mathrm{Mr}$. Davidson appears, in my opinion, to be right in the identification and, hence, in proposing that the name Schlotheimi should be abandoned for the older one crumena; for there is no character of importance in Martin's figures to distinguish them from the shell compared, nor is there, moreover, any other Carboniferous shell which can be considered to represent Martin's species.

Camarophoria globulina and C.rhomboidea.-Prof. King agrees, "with some reservation," in considering these shells to belong to one species. And the existence of Lingula Credneri* in the Coal-measures of Durham is also allowed, with "some slight reservation." As to Spiriferina cristata being the same as Sp. octiplicata, no definite opinion is expressed by the Professor. The tendency of his remarks seems to indicate a belief in their identity.

Terebratula elongata, var. suffata, and T. sacculus.-After a careful study of Prof. King's remarks on the first of these shells in regard to its existence during the Carboniferous epoch, I must confess myself still in some doubt as to what opinion he actually holds on the question. For instance, in the commencement of his remarks, he restates an opinion, expressed in the Monograph of Permian Fossils (Palæont. Soc.), to the following effect, that "sufflata appears to be identical with a shell found in the Mountain Limestone of Bolland." A little further on, it is said, quoting from the same work, that $T$. sufflata " undoubtedly lived in the Carboniferous epoch ;" but towards the conclusion of the paper it is stated, in a foot-note, that "I am more inclined to regard the 'Bolland shell' noticed in a previous page

* The supposed occurrence of this shell in the Lower Red Sandstone at Ferry Hill has led Prof. King to name that deposit "Lingula Sandstone" (Synoptical Table of British Rock Groups, 2nd edit.). Without inquiring whether there is the least occasion to alter a well-established subdivisional name, I would object to the adoption of the term "Lingula Sandstone" for a deposit in which the occurrence of Lingula is extremely doubtful. The only ground that exists for proposing this name at all is the fact of Prof. Johnson of Durham having told Prof. King that he had met with a Lingula in the above-named locality. But neither Prof. King nor any other palæontologist has ever seen a single example of this shell from the Lower Red Sandstone. And, with all deference to Prof. Johnson's scientific reputation, I see no improbability of his observation being at fault on a subject he had not investigated, when it is entirely opposed to the experience of all palæontologists who have pursued researches in the same district. But, granting that in one isolated instance this shell has occurred at Ferry Hill, is the sandstone to be specialized by the name of "Lingula" in consequence? A Lingula-Sandstone with no Lingula in it, nor even with a specimen to show that can be said to have been found in it! Such a misnomer should never be adopted. Nor is it any credit to geological nomenclature that it should ever have been proposed. 
as a variety of Dielasma (Terebratula) sacculus, and simulating D. sufflata, than as belonging to that species." Now, what is Prof. King's opinion on this question? Is it that T. sufflata is identical with the Bolland shell, and so recurrent from Carboniferous strata? or that it is a distinct species, and merely simulated in form by the Bolland shell? Both these opinions are given in the same paper; it is therefore impossible to see which expresses the views of its author. The former is, of course, that which I feel satisfied to be the correct one.

It would thus appear, in respect to the identification of the Permian and Carboniferous Brachiopods just noticed, that Prof. King in three cases is of the same opinion as $\mathrm{Mr}$. Davidson and myself, or, at least, that he allows three of the species to have had a Carboniferous and Permian existence, and that in two cases he has no decided opinion, while in one he disputes the identification. But notwithstanding that he only in one instance clearly differs from us in respect to the recurrency of the species, he occupies the conclusion of his paper in arguing against the method or "plan" of determining species that has been followed in identifying these Carboniferous and Permian fossils. Prof. King seems to consider that our views of species are too comprehensive, and that in some instances we include two or more distinct forms in one specific group. And in support of this opinion, he refers to the evidence to be derived from the study of recent shells, many of which, he asserts, would have had their specific identity ignored had they been determined on this plan as palæozoic fossils.

I am not aware myself of there being anything novel about the method on which these species have been determined, it having long been used by naturalists ; and it, moreover, seems to be the only one that it is possible to use, on the commonly received opinion of the individuality of species. For the sake of precision, however, I will briefly state what our method of determining species is; and in doing so I speak for Mr. Davidson as well as myself, our views on this subject being the same.

By species we understand groups of individuals characterized in common by peculiar features. These features or characters are considered to be persistent, and special to the groups they distinguish. Characters which are not persistent, but which are subject to essential modification, are looked upon as only of individual value. The great difficulty of palæontologists, as well as of other naturalists, is to distinguish in all cases between these two kinds of features or characters; for the latter kind often approach the former in apparent value; and it must be allowed that it is not always an easy matter to decide whether a 
character is of specific or individual worth. The principle, however, which we follow, in common with most naturalists, is to consider all features of individual value that graduate into other features, and all features of specific value that are not subject to such modification, but which stand out as marked characters in all comparisons with other forms. On this method the identifications of the preceding list have been made. Whenever a comparison of a Carboniferous with a Permian form showed that the supposed special characters of one passed, by gradual modification, into those of the other, and that there were no characters of the persistent type but such as were common to both forms, we have thought ourselves warranted in referring them to one species.

Further, we do not consider want of contemporaneity in fossils compared to be of any importance in determinations of species. Time is not, in our opinion, a circumstance that has anything to do with such decisions. And should two individuals present resemblances which we would consider specific in individuals of the same formation, we attach to them the same value, though they belong to separate formations. In both cases we grant equal importance to similar resemblances and differences. We are aware that this is not the principle that all palæontologists follow, - at least, that there are still a few who argue that want of contemporaneity is an element in determining species : and Prof. King, I suppose, adopts this method; for he refers to it in support of his opinion of Spirifera Clannyana being distinct from Sp. Urii. But we hold, with most palæontologists, that fossil species must be determined on natural-history merits alone, and not in any degree upon differences in their stratigraphical occurrence or geological age. The fact of specimens belonging to different formations ought to be put aside, and the decision arrived at on the same grounds as it is when the specimens are from a single stratum. Palæontologists who rely on this circumstance in distinguishing species rather remind me of those students of entomology who must first know the country of an insect before they venture to say what it is. The former would, moreover, appear to forget that systems and formations of strata are determined to be such by their species being generally distinct from those of other groups. No geologist would consider a series of strata a system or formation, if its fossils were not in the main peculiar. To contend, therefore, that fossils are different because they occur in different formations is to argue in a circle. The formation is first proved to be a formation because its species are principally distinct; and then the species are proved to be distinct because they occur in a different formation! 
Such is our method of determining species. And we are not inclined to allow Prof. King's charge of it being too dogmatic, nor yet that it is unsuggestive of philosophical conclusions. If naturalists and palæontologists carry out this method in their determinations of species, we shall perhaps ultimately know what is true and what is false philosophy in respect to them; for it will evidently tend to establish one of two things, - either that species with persistent characters do really exist, according to the old and more generally received opinion; or that there is, literally speaking, no such thing as persistent character, and hence no species except in the Darwinian or Lamarckian sense. And it is, perhaps, just as much in harmony with the spirit of true philosophy to search after truth thus inductively as it is to adopt hasty assumptions as to what truth is when the means of proving it are wanting.

It is further objected that our method involves a cumbrous nomenclature, and that it is wanting in "geologico-chronological" precision. It is asked if "Spirifera Urii, var. Clannyana, is not a cumbrous name?" I might ask, in return, what nomenclature has to do with the question. It is not concerned in the determination of species; at least, it should not be. I believe the general custom is for naturalists to make names for the species rather than species for the names, though there may be occasional exceptions; and the use of the varietal term Clannyana in addition to the specific name is optional, though the Permian specimens of this species scarcely seem to require so much importance. In respect to the want of "geologico-chronological" precision, I would also inquire if it is the object of nomenclature to express the chronological history of a species? When a shell occurs in two formations, it must of necessity be named alike in both. To signify, by the use of one term, that the shell is essentially the same on each horizon, is the first thing to be considered. Other considerations are of secondary importance.

In concluding his remarks, Prof. King draws the attention of palæontologists to the defective state of their knowledge of species compared with that which naturalists acquire of the recent forms. This, I think, no one will dispute. The acquaintance which the palæontologist can attain of species is at the best imperfect. He can have no direct knowledge of the softer parts of the animal : all anatomical details are lost to him; and, as Prof. King remarks, there are other characters which are generally beyond the pale of his investigation. But, without denying this in the least, there would still appear to be no reason for supposing that palæontologists have not materials enough left for the discrimination of species. It rarely happens that all the characters of a species are required in order to determine it; and 
differentiation of essential anatomical details, and of the more fragile characters, is usually accompanied by differences in those characters which survive fossilization. It is very rarely indeed that a shell is only known to be distinct on account of some anatomical peculiarity. I am therefore not disposed to think, as Prof. King seems to fear, that palæontologists will often arrive at erroneous conclusions in respect to species from their inability to employ all the means that are at the disposal of naturalists. And this opinion is borne out by what we know of such species as occur both fossil and recent. Take those of the Crag, for instance, or of any later Tertiary deposit, and it will be found that absence of colour, epidermis, opalescence, and of all anatomical details has not seriously interfered with their being properly discriminated. There seems, in my opinion, more reason to fear the creation of too many species by palæontologists than that any considerable number will be overlooked by them; for it should be remembered that there is a tendency in fossilization to produce differences where none exist, as well as to obliterate others that really characterize species. Fossils of one species preserved as casts, or in a semi-testiferous state, or with the shell in good condition, present very different appearances, and repeatedly lead to false determinations. And the fragmentary state in which some fossils occur, their being viewed in different aspects, and the various alterations effected by pressure and other causes, all tend to the adoption of species that have no real existence.

However, Prof. King, to illustrate his own views in respect to the influence that fossilization would have on recent shells, remarks that "nearly every British species of Mactra and Litorina, if occurring as fossils in palæozoic rocks, would have had their independent creation ignored, and have been respectively named Mactra multiformis and Litorina variabilis" on our method of determining species. Now, though these genera contain certain British species which could never have been confounded even as palæozoic fossils, Prof. King is assuredly aware that they are two of the most difficult groups of British shells, and that several of their reputed species are acknowledged to be mere varieties by most naturalists. Had they, therefore, occurred in palæozoic or any other rocks, the careful palæontologist would certainly have put many of their forms together, just, in fact, as the judicious conchologist does now. Thus the argument which Prof. King wishes to derive from these examples is rendered invalid by this fact; for it is certainly not to be expected that palæontologists would be able to see specific differences after fossililization, where naturalists for the most part denied their existence before that process. 
And the difficulty with which palæontologists have to contend from what Prof, King calls simulating forms is, I think, overstated. It is said by this authority that many existing shells have a tendency to simulate the distinctive features of other allied species; and, in support of this assertion, twelve British shells are mentioned, which Prof. King is satisfied would have been reduced to half the number had they occurred as palæozoic fossils. It may be observed, in the first place, that such shells as simulate the distinctive characters of others can be but questionable species at the best; and the conchologist would not, perhaps, be far wrong were he to anticipate the palæontologist by putting them together. This, in fact, has already been done in respect to some of the shells that Prof. King quotes, by most British naturalists. Astarte Danmoniensis and A. Scotica, for instance, are usually considered to be identical; and there are few conchologists who admit Mya Uddevallensis to be distinct from $M$. truncata - an opinion which Prof. King himself held some time ago, as appears by his paper published in 'Ann. Nat. Hist.' ser. 1. vol. xix. It is not to be denied, however, that several of the shells mentioned are good species; but, as most of them occur as Tertiary fossils, and have already been identified as distinct species*, they would not appear to run much risk of being confounded with others, even should they ultimately attain an age as great in comparison as palæozoic fossils at present.

\section{EXPLANATION OF PLATE IV.}

Fig. 1. Cythere (Bairdia) Schaurothiana, Kirkby. Carboniferous specimen, left valve. Craigenglen, Campsie.

Fig. 2. The same. Carboniferous specimen. Right valve. Craigenglen.

Fig. 11. The same. Carboniferous specimen. Lateral contour of left valve. Craigenglen.

Figs. 3, 4, 12. The same. Permian specimens, showing same aspects as before. Tunstall Hill.

Figs. 5, 6, 9. Cythere (Bairdia) plebeia, Reuss. Carboniferous specimens, showing left valve and lateral contour of same. Craigenglen, Campsie.

Figs. $7,8,10$. The same. Permian specimens, showing same aspects as last. Tunstall Hill.

[All the Entomostraca magnified 25 times.]

Fig. 13. Fenestella retiformis, Schloth. Permian. Non-celluliferous face ; magnified 6 times. Tunstall Hill.

* Lutraria oblonga and L. elliptica, for instance, occur together as fossils in the newer Tertiary beds of Sussex (Quart. Journ. Geol. Soc. vol. xiii. p. 51). In the same deposit Solen siliqua has been detected (ibid. p. 53); and in another Tertiary bed Solen ensis occurs (ib. vol. xiv. p. 328). Mya truncata and $M$. Uddevallensis also both occur in a fossil state (Woodward's 'Mollusca,' p. 357, and Quart. Journ. Geol. Soc. vol. xiii. p. 53). 
Fig. 16. The same. Permian. Celluliferous face, worn; magnified 12 times. Tunstall Hill.

Fig. 17. The same. Permian. Celluliferous face, unabraded; magnified 12 times. Tunstall Hill.

Fig. 15. The same (Fenestella plebeia, M'Coy). Carboniferous. Non-celluliferous face; magnified 6 times. Beith.

Figs. 14, 18. The same. Carboniferous. Celluliferous face, worn; magnified 12 times. Beith.

[Carboniferous specimens marked C; Permian specimens marked P.]

XXII._On Synapta digitata and its supposed Parasite. By A. BAUR*.

\section{The attachment of the Molluskigerous Sac to the head of the Synapta.}

THE point the elucidation of which is of most importance with regard to the relation of the sac-producing Mollusca to the Holothurid is the case, once seen by J. Müller, in which three molluskigerous sacs were attached within the head of the Synapta. J. Müller remained in doubt as to the meaning of this attachment, the mode of adhesion, and the nature of the outer extremity of the sac; he considered further observations upon the constancy or inconstancy of the attachment to the head to be necessary†.

Captures of Synapta digitata, continued during three months, furnished me repeatedly with molluskigerous sacs thus attached. It was also possible to examine more closely the mode of attachment, and to settle by observation the question whether it was constant or inconstant, whether it was accidental or connected with the origin of the molluskigerous sac, or perhaps with the immigration of the molluskigerous parasite.

While among 100-200 individuals of Synapta digitata it is not easy to find more than one infested by a molluskigerous sac, or now and then by several, there were three out of $120-130$ Synapte containing molluskigerous sacs, in which the sac, besides being attached as usual to the intestinal vessel, at the same time turned its ordinarily free and posteriorly directed end towards the head of the Synapta, and was attached there likewise. In all the three cases the sac attached to the head was of the same nature ; it differed, also, in no essential point from the others, which in other individuals extended freely backward into the body-cavity of the Synapta. None of the three mollus-

* Translated by W. S. Dallas, F.L.S., from the Monatsbericht der Akad. der Wiss. zu Berlin, April 1862, p. 187.

† J. Müller, "Ueber Synapta digitata und über die Erzeugung von Schnecken in Holothurien,' p. 15. (See 'Annals,' February 1852, p. 106.) 


\section{$2 \mathrm{BHL}$ Biodiversity Heritage Library}

Kirkby, James W. 1862. "XXI.-On some additional species that are common to Carboniferous and Permian strata; with remarks on the recurrency of Carboniferous species." The Annals and magazine of natural history; zoology, botany, and geology 10, 202-216.

View This Item Online: $\underline{\text { https://www.biodiversitylibrary.org/item/72075 }}$

Permalink: https://www.biodiversitylibrary.org/partpdf/60844

\section{Holding Institution}

University of Toronto - Gerstein Science Information Centre

\section{Sponsored by}

University of Toronto

\section{Copyright \& Reuse}

Copyright Status: NOT_IN_COPYRIGHT

This document was created from content at the Biodiversity Heritage Library, the world's largest open access digital library for biodiversity literature and archives. Visit BHL at https://www.biodiversitylibrary.org. 